\title{
AUTISM SPECTRUM DISORDER: A POSSIBLE LINK WITH CHONDROITIN SULFATE
}

Running head: ASD: a possible link with chondroitin sulfate

Eduardo Listik, M.Sc. Ph.D. ${ }^{\text {a,b }}$, Marcia Listik, M.D. ${ }^{c}$, Clarice Listik, M.Sc. M.D. ${ }^{\text {d, }}$ Leny Toma, Ph.D. ${ }^{a}$

${ }^{a}$ Department of Biochemistry, Universidade Federal de São Paulo. Rua Três de Maio, 100, São Paulo, SP, Brazil, CEP: 04044-020.

${ }^{b}$ Department of Pathology, University of Alabama at Birmingham, Birmingham AL, USA, 35294

${ }^{c}$ Listik Neuro Serviços Médicos, São Paulo, SP, Brazil. Rua Afonso Celso, 1629 cj. 42, São Paulo, SP, Brazil, CEP: 04119-062.

${ }^{c}$ Department of Neurology, Universidade de São Paulo. Universidade de São Paulo, Center of Movements Disorders, São Paulo SP, Brazil. CEP: 05402-000.

\section{Corresponding author:}

Eduardo Listik, Ph.D.

WTI 330F, 1824 Sixth Avenue South,

Birmingham, AL, 35233 .

E-mail: elistik@uabmc.edu

Phone: +1-205-934-6980/1

Funding: This work was supported by Fundação de Amparo à Pesquisa do Estado de São Paulo (FAPESP, grant number 2016/18066-6 to LT); and, in part, by the Coordenação de Aperfeiçoamento de Pessoal de Nível Superior - Brasil (CAPES) - Finance Code 001, including fellowship to EL.

Authors' contributions: ED Prepared all samples, performed data analysis, and drafted the initial manuscript. ML Collected data, carried out the patient care and selection. LT Performed gel electrophoresis. All authors reviewed and revised the manuscript.

Conflict of interest: The authors declare that they have no conflict of interest.

Keywords: Autism, Diagnostics, Developmental disorders, Glycosaminoglycan, Chondroitin sulfate 
medRxiv preprint doi: https://doi.org/10.1101/2020.10.15.20212910; this version posted October 20, 2020. The copyright holder for this preprint

(which was not certified by peer review) is the author/funder, who has granted medRxiv a license to display the preprint in perpetuity.

It is made available under a CC-BY-NC-ND 4.0 International license.

\section{ABSTRACT}

2 This study aimed to determine discrepancies in the urinary glycosaminoglycan profiles

3 of autism spectrum disorder (ASD) patients $(n=9)$ when compared with those from

4 healthy volunteers (HVs, n=3). The guardians and/or educators for each participant also

5 returned a validated Autism Behavior Checklist (ABC). The urinary chondroitin sulfate

6 (CS) concentration was $46.1 \%$ lower in the ASD group than in the HV group. The ABC

7 score and the urinary CS concentration were negatively correlated (Spearman's $\rho=-$

8 0.2635), indicating that as the severity of the clinical aspect of this disorder increased,

9 the urinary CS concentration decreased. These results suggest that low CS

10 concentrations in the urine may be associated with ASD, and could be measured using a

11 fast and low-cost method for diagnostics. 


\section{INTRODUCTION}

13 Autism spectrum disorder (ASD) are characterized by a lack of social interaction

14 and impaired verbal and non-verbal communication and can be diagnosed as early as

15 three years of age (Park et al., 2016).

Over the last two decades, ASD diagnoses have steadily increased (Fisch, 2012).

17 Some specialists have argued that this increase has been due to an expansion of the

18 diagnostic criteria and increased social awareness; however, newly diagnosed patients

19 appear to have similar profiles as those diagnosed using previous assessments, and the

20 new criteria do not seem to have influenced these results (Baio et al., 2018; Graf, Miller,

21 Epstein, \& Rapin, 2017). The diagnosis of ASD is observational and based on the

22 patient's behavior, although some biomarkers have been proposed (Galiana-Simal,

23 Munoz-Martinez, Calero-Bueno, Vela-Romero, \& Beato-Fernandez, 2018).

24 Glycosaminoglycans (GAGs) are complex polysaccharides, composed of

25 repeating disaccharide units. The composition of these units and their linking patterns

26 result in the formation of distinct GAGs, such as chondroitin sulfate (CS), dermatan

27 sulfate (DS) and heparan sulfate (HS) (Gandhi \& Mancera, 2008). GAGs may conjugate

28 with proteins, known as proteoglycans, and are essential for embryogenesis and

29 neuronal migration during development. CS proteoglycan mutations may be associated

30 with schizophrenia and bipolar disorder (Couchman, 2010; Iozzo \& Schaefer, 2015;

31 Maeda, 2015; Muhleisen et al., 2012; Nakato \& Li, 2016; Turner \& Grose, 2010).

32 Additionally, excreted GAGs in the urine may be used to diagnose

33 mucopolysaccharidoses (MPS) (Coutinho, Lacerda, \& Alves, 2012). Recently, the

34 genes associated with glycan synthesis have been thought to play a role in the

35 development of ASD (Dwyer \& Esko, 2016; Endreffy, Bjorklund, Dicso, Urbina, \&

36 Endreffy, 2016). Therefore, this study aimed to assess whether the concentrations of 
37 GAGs in the urine of ASD patients can be used to facilitate the diagnosis of ASD,

38 potentially resulting in a better understanding of the ASD pathophysiology and possible

39 therapeutic targets.

\section{METHODS}

41 Standard protocol approvals, registrations, and patient consents

All procedures performed in studies involving human participants were in

43 accordance with the ethical standards of the Institutional Ethics Committee of Research

$44\left(\mathrm{n}^{\mathrm{o}}\right.$ 14667219.0.0000.5505) and with the 1964 Helsinki declaration and its later

45 amendments or comparable ethical standards. Written informed consent/assent was

46 obtained from all participants or their guardians.

$47 \quad$ Patients and clinical assessments

48 A pediatric neurologist assessed patients with behavioral or communication

49 difficulties for the evaluation of a possible ASD diagnosis. Exclusion criteria were as

50 follows: younger than 2 years; older than 8 years; neurological lesions; mental

51 deficiency; and other diseases. Patients were also excluded if additional cases of ASD or

52 consanguinity were detected in their family histories. The same exclusion criteria were

53 applied to the healthy volunteers (HVs). The guardians and/or educators for all

54 participants were asked to respond to an electronic version of the validated Autism

55 Behavior Checklist (ABC), which is often used for its ability to identify children with

56 autism. (Marteleto \& Pedromonico, 2005) Both total scores and sub-scores were

57 calculated. The sub-scores included: sensory stimulus (SS), use of body and objects

58 (BO), language (LG), and personal-social development (PS). All participants had a

59 urine sample collected, which was stored at $-20{ }^{\circ} \mathrm{C}$ until processing.

\section{Glycosaminoglycan analysis}


62 supernatant were concentrated, using Amicon ${ }^{\circledR}$ Ultra centrifugal filters with a molecular

63 weight cut-off of $3 \mathrm{kDa}$ (Millipore, Massachusetts, USA), and the concentrate was

64 desalted using $10 \mathrm{mM} \mathrm{NaCl}$ (Sun et al., 2015).

65 Concentrated samples were applied to $0.6 \%$ agarose slabs, in diaminopropane-

66 acetate, $0.05 \mathrm{M}(\mathrm{pH} 9.0)$ buffer, and the GAGs were electrophoretically separated at 100

67 V for 60 min (Dietrich \& Dietrich, 1976; Jaques, Ballieux, Dietrich, \& Kavanagh,

68 1968). Gels were maintained in cetyltrimethylammonium bromide at $0.2 \%$ for $1 \mathrm{~h}$ and

69 dehydrated completely before being stained with a solution of $0.1 \%$ toluidine blue, $1 \%$

70 acetic acid and $50 \%$ ethanol for 20 min. The excess dye was removed with quick

71 washes of a destaining solution containing $1 \%$ acetic acid and $50 \%$ ethanol. The GAG

72 bands were densitometrically quantified and compared with an HS/DS/CS standard to

73 calculate the GAG concentrations in the urine.

\section{Data analysis}

75 GAG concentrations and ABC scores were compared between the HV and ASD 76 groups using a Mann-Whitney test, with $\mathrm{p}<0.05$ representing a significant difference.

77 The two variables were also examined for a possible correlation using Spearman's rank-

78 order correlation test. Variables were screened for outliers using the robust regression

79 and outlier removal test (ROUT's test).

\section{Data availability Statement}

81 All data associated with this study are available from the corresponding author, 82 upon reasonable request.

\section{RESULTS}


This study included 12 participants, nine who were diagnosed with ASD and three HVs. One ASD patient was excluded based on the ROUT's test results for the ABC scores, and one HV was excluded due to sample deterioration. The sample descriptors are summarized in Table 1.

Our data revealed that the ABC scores for the ASD patients $(63.5 \pm 23.4)$ were

89 significantly higher than those for the HVs $(5.0 \pm 2.8)$, as shown in Figure 1B. The ABC

90 sub-scores revealed that ASD patients received higher scores for all investigated

91 parameters, except for the relationship (RE) category (Figure 1B). The gel

92 electrophoresis for the assessment of GAG concentrations in the urine showed the

93 prevalence of CS, small signs of HS and none DS (Figure 1A) A significant reduction

$94(\mathrm{p}=0.04)$ of $46.1 \%$ in the CS concentrations was observed in the urine of ASD patients

95 compared with the urine of HV patients. Whereas ASD patients had a mean CS

96 concentration of $9.44 \pm 5.75 \mathrm{mg} / \mathrm{L}, \mathrm{HVs}$ had a considerably higher mean concentration

97 of $17.51 \pm 4.04 \mathrm{mg} / \mathrm{L}$ (Figure 1C).

98 Although a larger sample size would be necessary to estimate a precise 99 correlation between the two examined variables (i.e., ABC score $v s$. CS concentration in 100 urine), we observe that $\mathrm{ABC}$ scores for ASD patients were negatively correlated 101 (Spearman's $\rho=-0.2635$ ) with the measured GAG concentrations in the urine, which 102 could indicate that lower levels of CS in the urine may be associated with worse ASD 103 clinical diagnoses.

\section{DISCUSSION}

As previously mentioned, GAGs have been used to monitor MPS. During these

106 pathologies, CS, DS, HS or keratan sulfate (KS) can be observed in patient urine 107 samples, depending on the MPS (Coutinho et al., 2012). However, we discovered that 108 ASD patients display lower urinary CS concentrations for reasons that remain unknown. 
There is no corroborating evidence in the literature that would explain the lower

110 CS concentrations observed in the urine samples from ASD patients. The deletion of

111 EXT1, GPC5, GPC6, and mutation of HS3ST5 and SGSH, appear to be associated with

112 ASD (Dwyer \& Esko, 2016). These genes participate in HS synthesis, sulfation,

113 degradation, or HS proteoglycan synthesis. In addition, the deletion of B3GALT6, a

114 gene that affects both HS and CS synthesis, also appears to be implicated with ASD

115 (van der Zwaag et al., 2009).

116 The detection of GAGs in the urine may not be appropriate for the detection of

117 HS in these samples, as this GAGs was hardly detectable either in patients with ASD or

118 HVs urines; however, because the glycan balance may be altered in patients with ASD,

119 these alterations can be verified based on the CS concentrations, which revealed

120 significant discrepancies in this pilot study. A larger sample may establish whether

121 urinary CS concentrations can be utilized as a biomarker for ASD and help shed light on

122 the still unknown ASD pathophysiology, and this is a clear limitation of this study. In

123 addition, more studies with HS or specific proteoglycans in the blood or other samples

124 may also increase our understanding of ASD pathophysiology.

125 In this pilot study, we were able to infer that ASD patients may excrete less CS

126 in the urine, which can be assessed using a fast and low-cost analytical method.

\section{REFERENCES}

128 Baio, J., Wiggins, L., Christensen, D. L., Maenner, M. J., Daniels, J., Warren, Z., . . .

129 Dowling, N. F. (2018). Prevalence of Autism Spectrum Disorder Among

130 Children Aged 8 Years - Autism and Developmental Disabilities Monitoring

131 Network, 11 Sites, United States, 2014. MMWR Surveill Summ, 67(6), 1-23.

132 doi:10.15585/mmwr.ss6706a1 
medRxiv preprint doi: https://doi.org/10.1101/2020.10.15.20212910; this version posted October 20, 2020. The copyright holder for this preprint (which was not certified by peer review) is the author/funder, who has granted medRxiv a license to display the preprint in perpetuity.

It is made available under a CC-BY-NC-ND 4.0 International license .

133 Couchman, J. R. (2010). Transmembrane signaling proteoglycans. Annu Rev Cell Dev

134 Biol, 26, 89-114. doi:10.1146/annurev-cellbio-100109-104126

135 Coutinho, M. F., Lacerda, L., \& Alves, S. (2012). Glycosaminoglycan storage disorders:

136 a review. Biochem Res Int, 2012, 471325. doi:10.1155/2012/471325

137 Dietrich, C. P., \& Dietrich, S. M. (1976). Electrophoretic behaviour of acidic 138 mucopolysaccharides in diamine buffers. Anal Biochem, 70(2), 645-647.

139 Retrieved from http://www.ncbi.nlm.nih.gov/pubmed/131498

140 Dwyer, C. A., \& Esko, J. D. (2016). Glycan susceptibility factors in autism spectrum 141 disorders. Mol Aspects Med, 51, 104-114. doi:10.1016/j.mam.2016.07.001

142 Endreffy, I., Bjorklund, G., Dicso, F., Urbina, M. A., \& Endreffy, E. (2016). Acid 143 glycosaminoglycan (aGAG) excretion is increased in children with autism 144 spectrum disorder, and it can be controlled by diet. Metab Brain Dis, 31(2), 273145 278. doi:10.1007/s11011-015-9745-2

146 Fisch, G. S. (2012). Nosology and epidemiology in autism: classification counts. Am J 147 Med Genet C Semin Med Genet, 160C(2), 91-103. doi:10.1002/ajmg.c.31325

148 Galiana-Simal, A., Munoz-Martinez, V., Calero-Bueno, P., Vela-Romero, M., \& Beato149 Fernandez, L. (2018). Towards a future molecular diagnosis of autism: Recent 150 advances in biomarkers research from saliva samples. Int J Dev Neurosci, 67, 15. doi:10.1016/j.ijdevneu.2018.03.004

152 Gandhi, N. S., \& Mancera, R. L. (2008). The structure of glycosaminoglycans and their 153 interactions with proteins. Chem Biol Drug Des, 72(6), 455-482. 154 doi:10.1111/j.1747-0285.2008.00741.x 
155 Graf, W. D., Miller, G., Epstein, L. G., \& Rapin, I. (2017). The autism "epidemic":

156 Ethical, legal, and social issues in a developmental spectrum disorder. Neurology, 88(14), 1371-1380. doi:10.1212/WNL.0000000000003791

Iozzo, R. V., \& Schaefer, L. (2015). Proteoglycan form and function: A comprehensive nomenclature of proteoglycans. Matrix Biol, 42, 11-55. doi:10.1016/j.matbio.2015.02.003

161 Jaques, L. B., Ballieux, R. E., Dietrich, C. P., \& Kavanagh, L. W. (1968). A 162 microelectrophoresis method for heparin. Can J Physiol Pharmacol, 46(3), 351360. Retrieved from http://www.ncbi.nlm.nih.gov/pubmed/4177320

164 Maeda, N. (2015). Proteoglycans and neuronal migration in the cerebral cortex during development and disease. Front Neurosci, 9, 98. doi:10.3389/fnins.2015.00098

Marteleto, M. R., \& Pedromonico, M. R. (2005). Validity of Autism Behavior Checklist (ABC): preliminary study. Braz J Psychiatry, 27(4), 295-301. doi:/S1516-

Muhleisen, T. W., Mattheisen, M., Strohmaier, J., Degenhardt, F., Priebe, L., Schultz, C. C., . . . Cichon, S. (2012). Association between schizophrenia and common variation in neurocan (NCAN), a genetic risk factor for bipolar disorder. Schizophr Res, 138(1), 69-73. doi:10.1016/j.schres.2012.03.007

173 Nakato, H., \& Li, J. P. (2016). Functions of Heparan Sulfate Proteoglycans in Development: Insights From Drosophila Models. Int Rev Cell Mol Biol, 325, 275-293. doi:10.1016/bs.ircmb.2016.02.008 
medRxiv preprint doi: https://doi.org/10.1101/2020.10.15.20212910; this version posted October 20, 2020. The copyright holder for this preprint

(which was not certified by peer review) is the author/funder, who has granted medRxiv a license to display the preprint in perpetuity. It is made available under a CC-BY-NC-ND 4.0 International license.

176 Park, H. R., Lee, J. M., Moon, H. E., Lee, D. S., Kim, B. N., Kim, J., . . Paek, S. H.

177 (2016). A Short Review on the Current Understanding of Autism Spectrum

178 Disorders. Exp Neurobiol, 25(1), 1-13. doi:10.5607/en.2016.25.1.1

179 Sun, X., Li, L., Overdier, K. H., Ammons, L. A., Douglas, I. S., Burlew, C. C., . . .

180 Linhardt, R. J. (2015). Analysis of Total Human Urinary Glycosaminoglycan

181 Disaccharides by Liquid Chromatography-Tandem Mass Spectrometry. Anal

182 Chem, 87(12), 6220-6227. doi:10.1021/acs.analchem.5b00913

183 Turner, N., \& Grose, R. (2010). Fibroblast growth factor signalling: from development

184 to cancer. Nat Rev Cancer, 10(2), 116-129. doi:10.1038/nrc2780

185 van der Zwaag, B., Franke, L., Poot, M., Hochstenbach, R., Spierenburg, H. A.,

186 Vorstman, J. A., . . . Staal, W. G. (2009). Gene-network analysis identifies

187 susceptibility genes related to glycobiology in autism. PLoS One, 4(5), e5324.

188 doi:10.1371/journal.pone.0005324 
medRxiv preprint doi: https://doi.org/10.1101/2020.10.15.20212910; this version posted October 20, 2020. The copyright holder for this preprint

(which was not certified by peer review) is the author/funder, who has granted medRxiv a license to display the preprint in perpetuity.

It is made available under a CC-BY-NC-ND 4.0 International license.

\section{TABLES}

190 Table 1. Sample descriptors for ASD patients and HVs. The sample size, mean age,

191 distribution of sex, and ABC sub-scores and total score are shown for each group. The

192 number of individuals removed from each group is shown in the parentheses.

\begin{tabular}{|c|c|c|}
\hline Descriptor & ASD patients & HV \\
\hline Sample size & $9(-1)$ & $3(-1)$ \\
\hline Mean age & $3.9 \pm 1.1$ years & $8.0 \pm 0.0$ years \\
\hline Sex & All male & All male \\
\hline \multirow{3}{*}{ Ethnicity } & Caucasian $(88.9 \%)$ & \\
\hline & & Caucasian $(100 \%)$ \\
\hline & Asian $(11.1 \%)$ & \\
\hline ABC sensory stimulus (SS) & $8.6 \pm 4.4$ & $0.0 \pm 0.0$ \\
\hline $\mathrm{ABC}$ relationship (RE) & $10.6 \pm 7.2$ & $1.5 \pm 2.1$ \\
\hline $\mathrm{ABC}$ use of body and objects (BO) & $14.5 \pm 8.4$ & $0.0 \pm 0.0$ \\
\hline ABC language (LG) & $16.2 \pm 6.0$ & $0.0 \pm 0.0$ \\
\hline $\begin{array}{c}\text { ABC personal and social development } \\
\text { (PS) }\end{array}$ & $13.7 \pm 6.0$ & $3.5 \pm 0.7$ \\
\hline $\mathrm{ABC}$ total score & $63.5 \pm 23.4$ & $5.0 \pm 2.8$ \\
\hline
\end{tabular}

193 
medRxiv preprint doi: https://doi.org/10.1101/2020.10.15.20212910; this version posted October 20, 2020. The copyright holder for this preprint

(which was not certified by peer review) is the author/funder, who has granted medRxiv a license to display the preprint in perpetuity.

It is made available under a CC-BY-NC-ND 4.0 International license.

\section{FIGURE CAPTIONS}

195 Figure 1. Discrepancies in the CS concentrations in the urine between ASD patients

196 and HVs. (A) Processed urine samples were analyzed for GAG concentrations using an

197 electrophoretic method, in which CS was prevalent. S1 and S2 are the CS/DS/HS

198 standards, A1 - A9 (except A7 which was excluded) are ASD patients, and C2 and C3

199 are HVs. (B) ASD patients displayed significantly higher ABC scores than HVs. All of

200 the sub-scores, except for relationship (RE), were higher in ASD patients than in HVs.

201 The horizontal dotted line at $y=49$ indicates the scale cut-off. Other sub-scores

202 abbreviations: sensory stimulus (SS), use of body and objects (BO), language (LG), and

203 personal-social development (PS). (C) The measured CS concentration in the urine of

204 ASD patients is significantly lower than that in HVs. (D) A negative correlation

205 between ABC scores and CS concentration in urine, based on the Spearman's $\rho$. 
medRxiv preprint doi: https://doi.org/10.1101/2020.10.15.20212910; this version posted October 20, 2020. The copyright holder for this preprint (which was not certified by peer review) is the author/funder, who has granted medRxiv a license to display the preprint in perpetuity. It is made available under a CC-BY-NC-ND 4.0 International license.

\section{FIGURES}

A

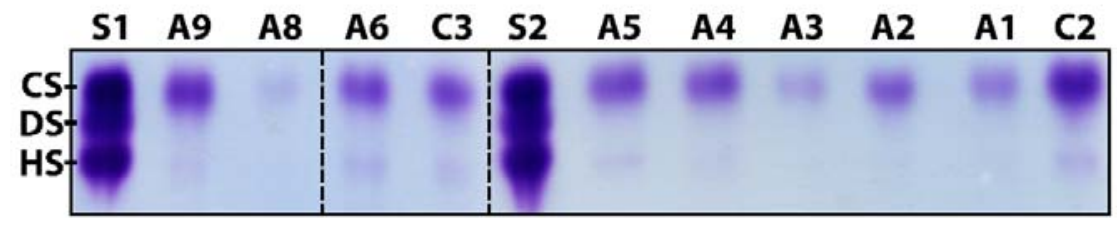

B

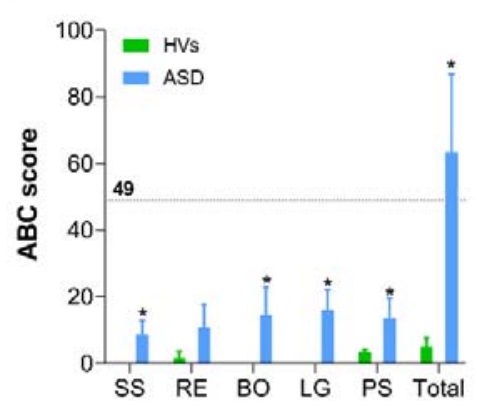

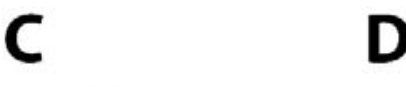
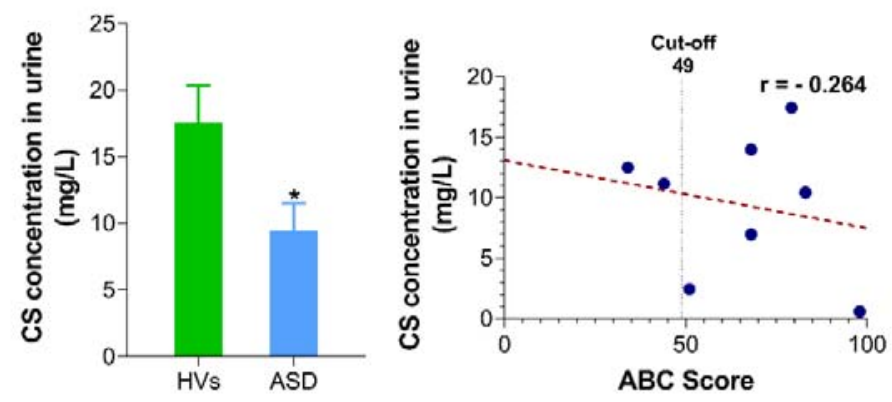